\title{
Optimalisasi Penjadwalan dengan Analisis Jaringan Kerja pada Kegiatan Verifikasi Koleksi Buku di Perpustakaan Sekolah
}

\author{
Muhammad Daut Siagian, Rosliana Siregar, Evi Adelina Nasution \\ Program Studi Pendidikan Matematika Uiversitas Islam Sumatera Utara, Jl. Sisingamangaraja, Teladan - Medan, 20217, Indonesia
}

\section{KEYWORDS}

Analisis Jaringan Kerja, Critical Path Method (CPM), Verifikasi Koleksi Buku.

\section{CORRESPONDENCE}

Phone: 0822-7729-0216

E-mail: mdsiagian@ fkip.uisu.ac.id

\section{A B S T R A K}

Penelitian ini membahas mengenai kegiatan verifikasi koleksi buku (stock opname) yang dilakukan di perpustakaan sekolah SMA Negeri 2 Medan. Metode yang digunakan untuk mengoptimalkan waktu penyelesaian kegiatan tersebut dengan network planning (analisa jaringan kerja) yaitu menerapkan Critical Path Method atau metode lintasan kritis. Hasil yang diperoleh dari pembahasan menunjukkan waktu optimal (waktu terpendek) untuk menyelesaikan kegiatan verifikasi koleksi buku tersebut adalah selama 41 hari dengan perkiraan waktu normal.

\section{PENDAHULUAN}

Perpustakaan sekolah merupakan bagian fasilitas yang terdapat di lingkungan sekolah dan dikelola sepenuhnya oleh pihak sekolah untuk membantu sekolah dalam mencapai tujuan pendidikan. Lasa [1] mengungkapkan bahwa terdapat beberapa fungsi penting perpustakaan sekolah, di antaranya adalah sebagai media pendidikan, untuk belajar, untuk melakukan penelitian sederhana, sebagai aplikasi teknologi informasi dalam alih dan pengembangan ilmu pengetahuan sebagai kelas alternatif serta sumber informasi

Sehingga dapat dipahami tujuan dari perpustakaan sekolah adalah sebagai wadah yang menyediakan berbagai ilmu pengetahuan melalui koleksi buku yang sesuai dengan kebutuhan siswa sehingga para siswa dapat mengembangkan bakat, mengeksplor dunia, serta menjadikan perpustakaan sekolah sebagai sumber menggali informasi.

Kasus rumitnya kegiatan verifikasi koleksi buku (stock opname) yang ada di perpustakaan menjadi topik yang menarik untuk dibahas dan dicari penyelesaiannya dengan menggunakan metode matematis. Kegiatan verifikasi koleksi buku tersebut dilakukan untuk mengetahui adanya buku yang hilang, buku yang salah penempatannya pada rak, buku yang perlu diperbaiki jilidan dan atribut lainnya serta untuk mengetahui buku yang perlu disisihkan dari jajaran koleksi. Verifikasi koleksi buku (stock opname) merupakan suatu kegiatan perhitungan kembali koleksi bahan pustaka yang dimiliki perpustakaan [2].

Pelaksanaan kegiatan verifikasi koleksi buku bertujuan untuk mengetahui jumlah bahan pustaka menurut golongan ilmunya, mengetahui koleksi buku yang hilang, memperoleh susunan buku yang rapi, dan untuk mengetahui kondisi fisik buku yang rusak atau tidak lengkap. Selain itu verifikasi koleksi buku (stock opname) juga bertujuan untuk merawat dan mengelola koleksi, data pada pangkalan data, shelflist, data peminjaman dan sebagainya.

Pelaksanaan kegiatan verifikasi koleksi buku ini dilakukan, pihak pengelola perpustakaan SMA Negeri 2 Medan mengharapkan kegiatan tersebut selesai selama 60 hari, namun pada kenyataannya saat kegiatan verifikasi koleksi buku dilakukan terjadi keterlambatan penyelesaian dari waktu yang telah ditentukan menjadi lebih dari 60 hari. Hal tersebut dikarenakan tidak terjadwalnya waktu penyelesaian masingmasing kegiatan verifikasi koleksi buku. Hal ini tentu harus menjadi pertimbangan bagi pengelola perpustakaan dalam mengatur jadwal pelaksanaan kegiatan verifikasi koleksi buku secara tepat demi kenyamanan kerja pengelola perpustakaan dan pengguna layanan perpustakaan. Sehingga kegiatan verifikasi koleksi buku dapat selesai pada waktu yang telah ditetapkan. Salah satu cabang matematika yang mampu menyelesaikan permasalahan tersebut adalah dengan menggunakan analisis jaringan kerja.

Untuk mengetahui jadwal kegiatan verifikasi pada kegiatan verifikasi koleksi buku diperpustakaan dapat menerapkan analisis jaringan kerja, sehingga tidak terjadi kelambatan dalam kegiatan verifikasi dan kegiatan ini dapat berjalan dengan lancar [3]. Analisis jaringan kerja dapat mengendalikan waktu pelaksanaan kegiatan verifikasi koleksi 
buku dengan membentuk jalur kritis dari rangkaian kegiatan tersebut. Hal ini tentu sangat bermanfaat dalam pengambilan keputusan atau penentuan kebijakan oleh pihak pengelola perpustakaan dalam melaksanakan kegiatan verifikasi koleksi buku.

Penggunaan analisis jaringan kerja dalam suatu proyek bertujuan untuk memantau semua unsur proyek ke dalam suatu rencana utama, dengan membangun suatu model kerja untuk melengkapi suatu proyek sehingga diperoleh waktu yang efisien (terbaik) dalam melakukan pekerjaan atau kegiatan, pengurangan biaya, meminimalkan resiko, pemanfaatan sumber-sumber secara lebih hemat, mendapatkan atau mengembangkan jadwal (schedule) yang optimum, memudahkan revisi atau perbaikan terhadap penyimpangan yang terjadi. Dengan analisis jaringan kerja kita dapat menyelesaikan suatu masalah dengan menyajikannya menjadi suatu diagram jaringan kerja sehingga persoalan yang kompleks dapat diselesaikan secara lebih sederhana dan sistematis.

\section{METODE}

Penelitian ini dilakukan di Perpustakaan sekolah SMA Negeri 2 Medan dengan menerapkan analisis jaringan kerja dalam mengendalikan waktu penyelesaian kegiatan verifikasi koleksi buku dengan menerapkan tahapan-tahapan berikut:

1. Menyusun daftar kegiatan verifikasi koleksi buku.

2. Menentukan kegiatan pendahulu langsung dari setiap kegiatan verifikasi koleksi buku.

3. Mengestimasi waktu penyelesaian dari setiap kegiatan verifikasi koleksi buku.

4. Membuat diagram jaringan kerja yang menggambarkan kegiatan dan pendahulu langsung yang terdaftar dalam langkah 1 dan 2.

5. Menentukan waktu kejadian paling cepat (WKC) dengan cara forward pass melalui diagram jaringan kerja.

6. Menentukan waktu kejadian paling lambat (WKL) dari dengan cara backward pass melalui diagram jaringan kerja.

7. Menentukan nilai waktu mengambang total (WMT) dan waktu mengambang bebas (WMB) untuk setiap kegiatan.

Setiap prosedur yang dilakukan dalam penelitian ini dijelaskan secara rinci berikut ini:

Sistematika Jaringan Kerja

Menurut Ayu [4] langkah-langkah sistematika proses penyusunan jaringan kerja yaitu:

a. Langkah Pertama

Mengidentifikasi lingkup proyek, menguraikan atau memecahkannya menjadi kegiatan-kegiatan atau kelompok kegiatan yang merupakan komponen proyek. Identifikasi yang dimaksud adalah untuk mengetahui kegiatan-kegiatan yang merupakan bagian atau komponen dari proyek yang bisa dibedakan satu sama lain.

b. Langkah Ke-Dua

Membuat kembali komponen-komponen tersebut pada butir pertama, menjadi mata rantai dengan urutan yang sesuai dengan logika ketergantungan. Urutan ini dapat berbentuk pararel atau seri. Membuat urutan ketergantungan, dalam hal ini dituntut berpikir secara analitis, sehingga akan diperoleh urutan yang merupakan solusi permasalahan.

c. Langkah Ke-Tiga

Mengestimasi kurun waktu masing-masing kegiatan yang dihasilkan dari penguraian lingkup proyek. Mengestimasi kurun waktu ke analisis jaringan kerja, dalam hal ini perencanaan telah memasuki fase yang lebih spesifik, yaitu membuat jadwal kegiatan proyek.

d. Langkah Ke-Empat

Mengidentifikasi jalur kritis (critical path) pada diagram jaringan kerja. Jalur kritis adalah jalur yang terdiri dari rangkaian kegiatan dari lingkup proyek, yang apabila terlambat, maka akan menyebabkan keterlambatan proyek secara keseluruhan.

e. Langkah Ke-Lima

Melanjutkan dengan usaha-usaha meningkatkan daya guna dan hasil guna pemakaian sumber daya, yang meliputi kegiatan:

1) Menentukan jadwal yang paling ekonomis

2) Meminimalkan fluktuasi pemakaian sumber daya

Setelah jadwal dan rencana proyek tersusun dengan cukup realistik, selanjutnya sebagai alat pembanding dalam kegiatan pengendalian pada tahap inplementasi fisik dapat dilakukan dengan membandingkan antara perencanaan atau jadwal dengan hasil pelaksanaan nyata dilapangan.

\section{Diagram Jaringan Kerja}

Diagram jaringan kerja merupakan logika model yang menggambarkan hubungan antara masing-masing kegiatan dan menjelaskan arus dari operasi sejak awal hingga selesainya kegiatan-kegiatan proyek. Diagram jaringan kerja berperan sebagai alat perencanaan proyek dan sebagai ilustrasi secara grafik dari kegiatan-kegiatan suatu proyek [4]. Oleh karena itu, diagram jaringan kerja harus mampu memberi gambaran tentang dimulainya suatu kegiatan sampai diselesaikannya kegiatan tersebut.

\section{Menyusun Urutan Kegiatan}

Proses pembuatan diagram jaringan kerja, didasarkan atas logika ketergantungan untuk menyusun urutan kegiatan atau hubungan kegiatan yang satu dengan yang lain. Hal ini merupakan bagian dari aturan dasar dalam menyusun diagram jaringan kerja. Diagram jaringan kerja tersebut memperlihatkan ketergantungan logika antar kegiatan yang saling berurutan dari awal sampai akhir kegiatan.

\section{Critical Path Method (CPM)}

Critical Path Method atau metode jalur kritis yang dikembangkan oleh E. I. Du Pont de Nemours dan Corporation untuk melaksanakan berbagai proyek yang dikembangkan. CPM merupakan penentuan waktu terpendek yang dibutuhkan dalam menyelesaikan suatu proyek atau menentukan jalur waktu terlama [5]. CPM digunakan untuk perencanaan dan pengendalian proyek dan merupakan cara yang paling banyak digunakan di antara banyak cara yang menggunakan prinsip pembentukan diagram jaringan kerja. Pelaksanaan proyek dengan CPM menggunakan critical path, yaitu jalur yang memiliki rangkaian komponen-komponen kegiatan, dengan total jumlah waktu terlama dan waktu tercepat dalam penyelesaian proyek. Jalur kritis terdiri atas rangkaian kegiatan kritis, dimulai dari kegiatan awal sampai akhir proyek. Penentuan jalur kritis penting dilakukan bagi pelaksanaan proyek, karena pada jalur kritis terletak kegiatan-kegiatan yang apabila pelaksanaannya terlambat, maka akan memperngaruhi keterlambatan proyek secara keseluruhan. Oleh karena itu, dengan adanya jalur kritis, dapat menentukan waktu penyelesaian suatu proyek secara cepat atau lambat.

\section{Optimalisasi Waktu}

Optimalisasi dimaknai sebagai penyederhanaan masalah dan membatasi faktor-faktor yang mungkin berpengaruh terhadap suatu masalah [6]. Optimalisasi juga diartikan sebagai pengoptimalan, yaitu proses, cara, perbuatan untuk menghasilkan yang paling baik. Optimalisasi pada umunya dilakukan untuk mengoptimalkan sumber daya yang ada serta mengurangi resiko sehingga mendapatkan hasil yang optimal.

Perhitungan waktu kejadian paling cepat (WKC) dan waktu kejadian paling lambat (WKL) dapat dilakukan dengan terlebih dahulu menggambarkan diagram jaringan kerja, yang memuat waktu yang dibutuhkan untuk menyelesaikan setiap kegiatan. Setelah itu, waktu kejadian paling cepat (WKC) dan waktu kejadian paling lambat (WKL) dapat dihitung dengan cara forward pass dan backwasd pass.

a. Forward Pass

Forward pass dimulai dari kiri ke kanan sampai kejadian akhir, atau dengan kata lain dimulai dari kejadian awal 
sampai akhir. Tujuan dari forward pass adalah untuk menghitung waktu kejadian paling cepat (WKC) untuk setiap kejadian dalam suatu proyek. Setelah selesai menghitung waktu kejadian paling cepat (WKC), dapat juga dihitung waktu mulai paling cepat (WMC) dan waktu selesai paling cepat (WSC) setiap kegiatan dengan cara forward pass.

b. Backward Pass

Backward pass kebalikan dari forward pass yaitu memulai kejadian dari kanan ke kiri, atau dengan kata lain dimulai dari kejadian paling akhir sampai kejadian paling awal. Tujuan dari backward pass adalah untuk menghitung waktu kejadian paling lambat (WKL) untuk setiap kejadian. Selain menghitung waktu kejadian paling lambat (WKL) untuk setiap kejadian, juga dapat ditentukan waktu mulai paling lambat (WML) dan waktu selesai paling lambat (WSL) untuk setiap kegiatan.

\section{Jalur Kritis}

Jalur kritis merupakan jalur terpanjang pada network dan waktunya menjadi waktu penyelesaian minimum yang diharapkan untuk masing-masing alternatif (Handoko, 2000). Kegunaan jalur kritis adalah untuk mengetahui kegiatan yang memiliki kepekaan sangat tinggi atas keterlambatan penyelesaian pekerjaan. Apabila terjadi keterlambatan proyek pada kegiatan kritis, maka akan memperlambat penyelesaian proyek secara keseluruhan meskipun kegiatan lain tidak mengalami keterlambatan.

\section{Waktu Mengambang}

Waktu mengambang merupakan waktu suatu kegiatan dapat ditunda mulainya tanpa menunda proyek secara keseluruhan dan waktu mengambang adalah selisih waktu paling lambat (WKL) dan waktu paling cepat (WKC). Waktu mengambang diartikan sebagai sejumlah waktu yang tersedia dalam suatu kegiatan sehingga memungkinkan penundaan atau perlambatan kegiatan tersebut secara sengaja atau tidak sengaja tetapi penundaan tersebut tidak menyebabkan proyek menjadi terlambat dalam penyelesaiannya [7][8].

\section{Mempercepat Umur Proyek}

Maranresy,dkk [5][9][10]syarat yang harus dipenuhi agar dapat membuat rencana dengan umur proyek yang lebih cepat daripada keadaan semula adalah: a) Membuat network diagram; b) Menentukan lama kegiatan perkiraan masing-masing kegiatan; c) Menghitung waktu kejadian paling cepat (WKC) dan waktu kejadian paling lambat (WKL) semua kejadian; dan d) Menentukan umur rencana proyek (UREN)

Prosedur Mempercepat Umur Proyek.

Prosedur yang harus diikuti agar dapat mempercepat umur proyek adalah:

a. Membuat network diagram dengan nomor-nomor kejadian sama seperti semula dengan lama kegiatan perkiraan baru untuk langkah ulang, dan sama dengan semula untuk langkah siklus pertama.

b. Menentukan $\mathrm{WKC}_{1}$ dengan dasar waktu kejadian paling cepat, $\mathrm{WKC}_{1}=0$, dihitung waktu kejadian paling cepat lainnya. Umur perkiraan proyek $($ UPER $)=$ waktu kejadian paling cepat kejadian akhir (WKCj, j adalah nomor kejadian akhir network diagram atau nomor maksimal kejadian). c. Menentukan $\mathrm{WKL}_{\mathrm{j}}$ dengan dasar waktu kejadian paling lambat kejadian akhir network diagram $(\mathrm{WKLj})=$ umur proyek yang direncanakan (UREN), dihitung waktu kejadian paling lambat semua kejadian.

d. Menghitung waktu mengambang total (WMT) semua kegiatan yang ada. Jika tidak ada waktu mengambang total (WMT) yang bernilai negatif, maka proses perhitungan selesai. Jika masih ada waktu mengambang total bernilai negatif, maka hitung kembali waktu mengambang total (WMT) sampai bernilai positif.

e. Mencari lintasan atau lintasan-lintasan yang terdiri dari kegiatan-kegiatan yang waktu mengambang total masingmasing kegiatan.

WMT = UREN- UPER

$$
\begin{aligned}
& =\mathrm{WKL}_{\mathrm{j}}-\mathrm{WKC}_{\mathrm{j}} \\
& =\mathrm{WKL}_{1}-\mathrm{WKC}_{1}
\end{aligned}
$$

f. Menentukan lama kegiatan dari kegiatan tersebut adalah: Ln, $\mathrm{n}$ adalah nomor urut kegiatan tersebut dalam satu lintasan, $\mathrm{n}=1,2,3, \ldots . . \mathrm{z}$

g. Menghitung lama kegiatan baru dari kegiatan sebelumnya (langkah ke-5 dan 6) dengan menggunakan rumus sebagai berikut:

$$
\mathrm{L}_{\mathrm{n}}(\text { baru })=\mathrm{L}_{\mathrm{n}}(\text { lama })+\frac{\mathrm{L}_{\mathrm{n}}(\text { lama })}{\mathrm{L}_{\mathrm{i}}} \times(\text { UREN }- \text { UPER })(2)
$$

h. Kembali ke langkah pertama

Percepatan durasi pada salah satu kegiatan pengikut (successor) dan memeriksa kemungkinan kegiatan pengikut dapat dilakukan percepatan, dengan batasan sebagai berikut:

a. Durasi percepatan lebih besar dari pada nilai waktu mengambang (d's > waktu mengambang) kegiatan pengikut (successor).

b. Durasi kegiatan rencana pengikut harus lebih besar dari dua kali keterlambatan proyek agar memungkinkan untuk optimalisasi durasi sampai $50 \%$ dari keterlambatan proyek.

\section{HASIL DAN PEMBAHASAN}

Pada penelitian ini, ditentukan jalur kritis dalam penjadwalan kegiatan verifikasi koleksi buku yang dilakukan di perpustakaan sekolah SMA Negeri 2 Medan dengan menggunakan analisis jaringan CPM (Critical Path Method). Kegiatan verifikasi koleksi buku yang dilakukan di perpustakaan tersebut disusun daftar kegiatan verifikasi, kegiatan pendahulu dan pengikut, lama pelaksanaan masing-masing kegiatan dan gambar diagram jaringan kerja.

Berdasarkan diagram jaringan kerja tersebut dapat dilakukan perhitungan maju (forward pass) dan perhitungan mundur (backward pass) dalam menentukan jalur kritis dari kegiatan verifikasi koleksi buku yang dilakukan dengan menggunakan analisis jaringan CPM. Kegiatan verifikasi koleksi buku (stock opname) yang dilakukan di perpustakaan SMA Negeri 2 Medan meliputi berbagai macam kegiatan yang dapat dilihat pada Tabel 1.

Tabel 1. Daftar Kegiatan Verifikasi Koleksi Buku

\begin{tabular}{clccc}
\hline No & \multicolumn{1}{c}{ Kegiatan } & Kode & $\begin{array}{c}\text { Kegiatan } \\
\text { Sebelumnya }\end{array}$ & $\begin{array}{c}\text { Lama } \\
\text { Pelaksanaan }\end{array}$ \\
\hline 1 & Menentukan pembagian tugas untuk masing-masing petugas & A & - & 1 Hari \\
\hline 2 & $\begin{array}{l}\text { Membersihkan koleksi buku dari debu dengan menggunakan lap } \\
\text { pembersih atau vaccum cleaner }\end{array}$ & B & A & 7 Hari \\
\hline 3 & $\begin{array}{l}\text { Mengeluarkan semua koleksi dari rak dan memeriksa serta merapikan } \\
\text { susunan bahan pustaka berdasarkan nomor kelas /call number }\end{array}$ & C & B & 7 Hari \\
\hline 4 & Mencetak data bahan pustaka yang ada pada pangkalan data & D & C & 1 Hari \\
\hline 5 & $\begin{array}{l}\text { Membagikan daftar data koleksi yang ada pada pangkalan data kepada } \\
\text { petugas sesuai dengan tugasnya }\end{array}$ & E & D & 1 Hari \\
\hline
\end{tabular}




\begin{tabular}{cllcl}
\hline 6 & $\begin{array}{l}\text { Melacak keberadaan koleksi dengan cara mencocokan daftar bahan } \\
\text { pustaka dengan koleksi yang ada di rak. }\end{array}$ & $\mathrm{F}$ & $\mathrm{E}$ & 2 Hari \\
\hline 7 & $\begin{array}{l}\text { Memberi tanda khusus pada daftar jika koleksi tidak ditemukan, maka } \\
\text { kemungkinan buku tersebut sedang dipinjam, rusak/dijilid, hilang }\end{array}$ & $\mathrm{G}$ & $\mathrm{F}$ & 2 Hari \\
\hline 8 & $\begin{array}{l}\text { Menghapus data buku pada pangkalan data bagi buku yang dinyatakan } \\
\text { hilang }\end{array}$ & $\mathrm{H}$ & $\mathrm{G}$ & 1 Hari \\
\hline 9 & $\begin{array}{l}\text { Memberi tanda pada buku-buku yang tidak lengkap atau dalam kondisi } \\
\text { rusak untuk segera diperbaiki }\end{array}$ & $\mathrm{I}$ & $\mathrm{G}$ & 1 Hari \\
\hline 10 & $\begin{array}{l}\text { Memeriksa kembali kelengkapan data bibliografi (buku ada di daftar dan } \\
\text { juga di rak koleksi), apabila tidak lengkap tambahkan data, dan simpan } \\
\text { kembali koleksi pada tempat yang seharusnya }\end{array}$ & $\mathrm{J}$ & $\mathrm{F}$ & 1 Hari \\
\hline 11 & $\begin{array}{l}\text { Memberi catatan jumlah eksemplar pada data koleksi di pangkalan data } \\
\text { Mengolah dan memasukkan data buku-buku yang ada di rak tetapi tidak } \\
\text { ada pada pangkalan data }\end{array}$ & $\mathrm{K}$ & $\mathrm{F}$ & $\mathrm{F}$ \\
\hline 13 & $\begin{array}{l}\text { Memasukkan kembali buku-buku ke dalam jajaran koleksi yang benar } \\
\text { sesuai dengan nomor panggil (call number). }\end{array}$ & $\mathrm{M}$ & $\mathrm{H}, \mathrm{I}, \mathrm{J}, \mathrm{K}, \mathrm{L}$ & 7 Hari \\
\hline 14 & $\begin{array}{l}\text { Menghitung jumlah judul dan eksemplar koleksi berdasarkan data pada } \\
\text { pangkalan data }\end{array}$ & $\mathrm{N}$ & $\mathrm{M}$ \\
\hline 15 & $\begin{array}{l}\text { Membuat laporan jumlah judul dan eksemplar koleksi yang ada, hilang, } \\
\text { dipinjam, dijilid, dan sebagainya }\end{array}$ & $\mathrm{O}$ & $\mathrm{N}$ & 7 Hari \\
\hline
\end{tabular}

Berdasarkan jenis dan perkiraan waktu masing-masing kegiatan

Negeri 2 Medan, dapat digambarkan diagram jaringan kerja pada dalam kegiatan verifikasi koleksi buku di perpustakaan SMA

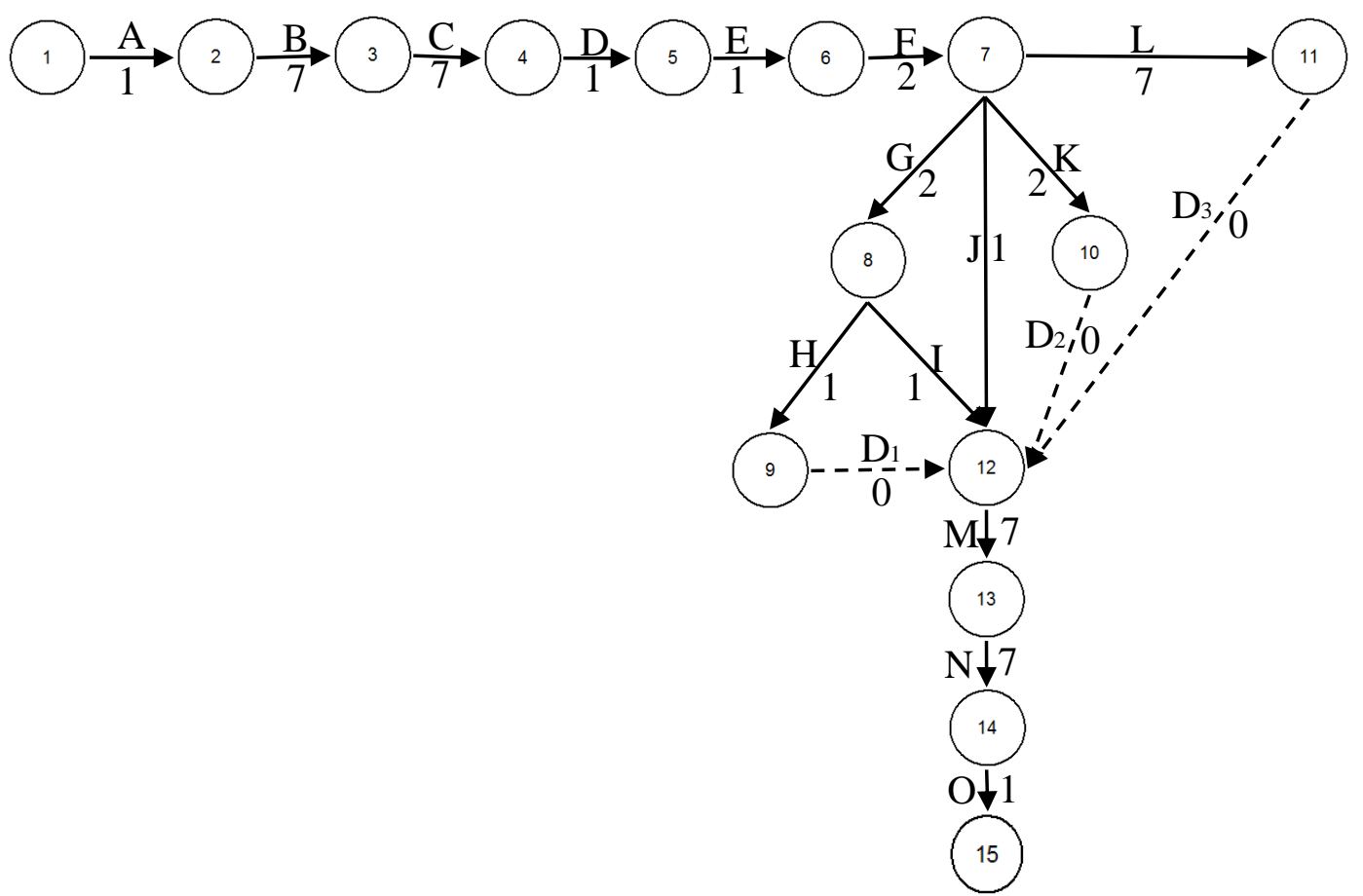

Gambar 1. Diagram Jaringan Kerja pada Kegiatan Verifikasi Koleksi Buku di Perpustakaan Sekolah SMA Negeri 2 Medan

\section{Analisis Waktu untuk Tahapan Kerja}

Waktu kejadian paling cepat diperoleh dengan membuat suatu langkah ke kanan melalui diagram jaringan kerja, dimulai dengan kejadian awal dan berlangsung ke kanan menuju kejadian akhir atau dengan cara forward pass. Waktu kejadian paling cepat (WKC), dapat dihitung dengan menggunakan rumus sebagai berikut:
$\mathrm{WKC}_{\mathrm{j}}=$ maks $\left(\mathrm{WKC}_{\mathrm{i}}+\mathrm{W}_{\mathrm{ij}}\right)$ untuk semua kegiatan $(\mathrm{i}, \mathrm{j})(3)$

Berdasarkan waktu kejadian paling cepat yang dihitung dapat digambarkan diagram jaringan kerja yang memuat waktu kejadian paling cepat pada Gambar 2. 


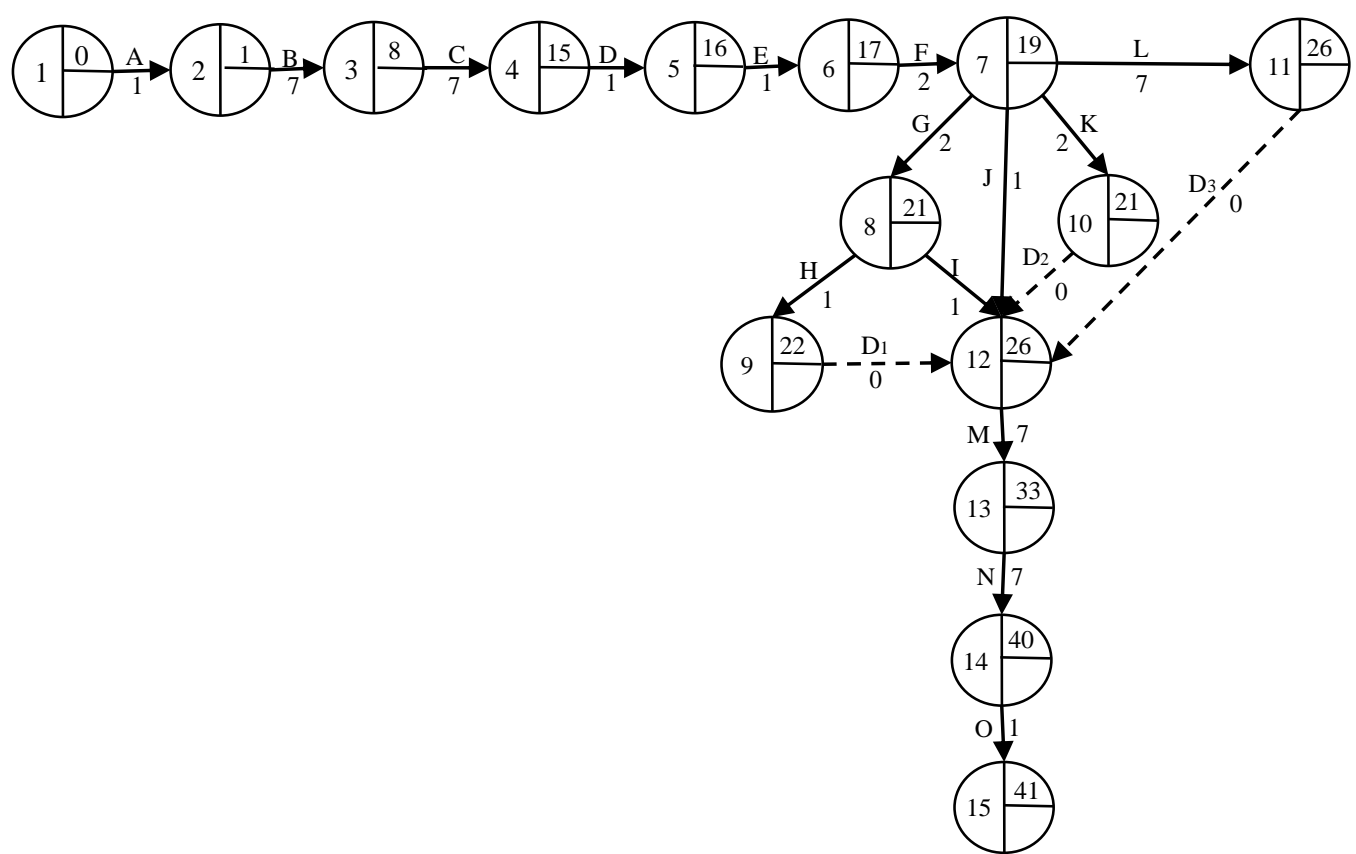

Gambar 2. Diagram Jaringan Kerja yang Memuat Waktu Kejadian Paling Cepat pada Setiap Kejadian

Setelah dihitung waktu kejadian paling cepat (WKC) dari kegiatan verifikasi koleksi buku yang dilakukan di SMA Negeri 2 Medan, dapat juga dihitung waktu mulai paling cepat (WMC) dan waktu selesai paling cepat (WSC) kegiatan verifikasi koleksi buku seperti pada Tabel 2 .

Tabel 2. Waktu Mulai Paling Cepat (WMC) dan Waktu Selesai Paling Cepat (WSC) Kegiatan Verifikasi Koleksi Buku

\begin{tabular}{|c|c|c|c|c|}
\hline Kegiatan & Kode Kegiatan & Waktu Kegiatan $\left(W_{i j}\right)$ & $(\mathbf{W M C})_{\mathrm{ij}}$ & $(\mathbf{W S C})_{\mathrm{ij}}$ \\
\hline $\mathrm{A}$ & 1,2 & 1 & 0 & 1 \\
\hline B & 2,3 & 7 & 1 & 8 \\
\hline $\mathrm{C}$ & 3,4 & 7 & 8 & 15 \\
\hline $\mathrm{D}$ & 4,5 & 1 & 15 & 16 \\
\hline $\mathrm{E}$ & 5,6 & 1 & 16 & 17 \\
\hline $\mathrm{F}$ & 6,7 & 2 & 17 & 19 \\
\hline G & 7,8 & 2 & 19 & 21 \\
\hline $\mathrm{H}$ & 8,9 & 1 & 21 & 22 \\
\hline $\mathrm{I}$ & 8,12 & 1 & 21 & 22 \\
\hline $\mathrm{J}$ & 7,12 & 1 & 19 & 20 \\
\hline K & 7,10 & 2 & 19 & 21 \\
\hline $\bar{L}$ & 7,11 & 7 & 19 & 26 \\
\hline $\mathrm{D}_{1}$ & 9,12 & 0 & 22 & 22 \\
\hline $\mathrm{D}_{2}$ & 10,12 & 0 & 21 & 21 \\
\hline $\mathrm{D}_{3}$ & 11,12 & 0 & 26 & 26 \\
\hline M & 12,13 & 7 & 26 & 33 \\
\hline $\mathrm{N}$ & 13,14 & 7 & 33 & 40 \\
\hline $\mathrm{O}$ & 14,15 & 1 & 40 & 41 \\
\hline
\end{tabular}

Setelah didapat waktu kejadian paling cepat (WKC) dari setiap kejadian, selanjutnya menghitung waktu kejadian paling lambat (WKL) dari masing-masing kegiatan. Waktu kejadian paling lambat (WKL) dihitung dengn cara backward pass yaitu dimulai dari kejadian akhir menuju kejadian awal. Waktu kejadian paling lambat (WKL) dapat dihitung dengan menggunakan rumus:

$$
\mathrm{WKL}_{\mathrm{i}}=\min \left(\mathrm{WKL}_{\mathrm{j}}-\mathrm{W}_{\mathrm{ij}}\right), \mathrm{i}<\mathrm{j}
$$

Berdasarkan waktu kejadian paling lambat (WKL) yang dihitung dapat digambarkan diagram jaringan kerja sebagai berikut. 


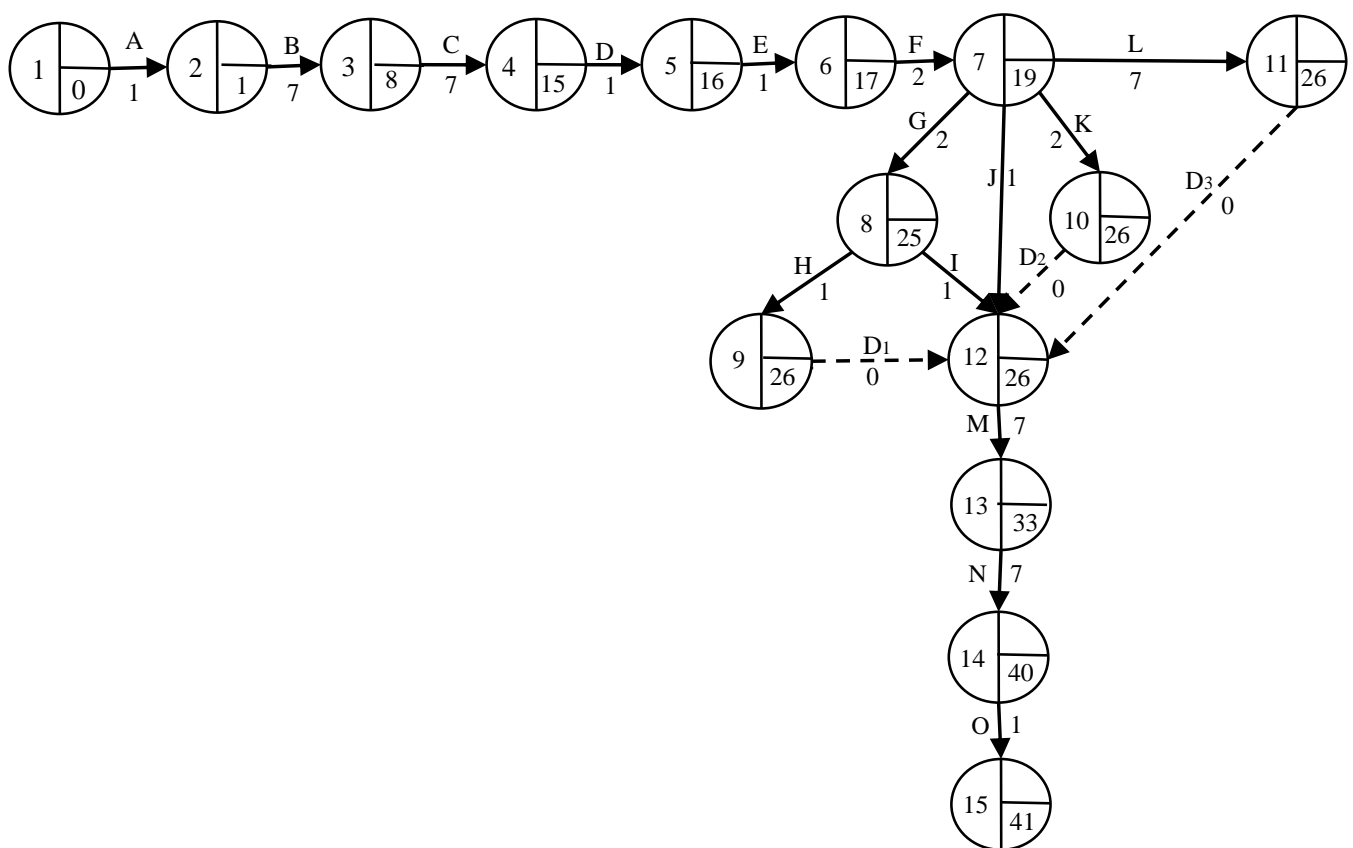

Gambar 3. Diagram Jaringan Kerja yang Memuat Waktu Kejadian Paling Lambat pada Setiap Kejadian

Setelah dihitung waktu kejadian paling lambat (WKL) dari kegiatan verifikasi koleksi buku yang dilakukan di SMA Negeri 2 Medan, dapat juga dihitung waktu mulai paling lambat (WML) dan waktu selesai paling lambat (WSL) kegiatan verifikasi koleksi buku seperti pada Tabel 3.

Tabel 3. Waktu Mulai Paling Lambat (WML) dan Waktu Selesai Paling Lambat (WSL) Kegiatan Verifikasi Koleksi Buku

\begin{tabular}{|c|c|c|c|c|}
\hline Kegiatan & Kode Kegiatan & $\begin{array}{c}\text { Waktu Kegiatan } \\
\left(\mathbf{W}_{\mathrm{ij}}\right)\end{array}$ & $(\mathbf{W M L})_{\mathrm{ij}}$ & $(\mathbf{W S L})_{\mathrm{ij}}$ \\
\hline A & 1,2 & 1 & 0 & 1 \\
\hline B & 2,3 & 7 & 1 & 8 \\
\hline $\mathrm{C}$ & 3,4 & 7 & 8 & 15 \\
\hline $\mathrm{D}$ & 4,5 & 1 & 15 & 16 \\
\hline $\bar{E}$ & 5,6 & 1 & 16 & 17 \\
\hline $\mathrm{F}$ & 6,7 & 2 & 17 & 19 \\
\hline $\mathrm{G}$ & 7,8 & 2 & 23 & 25 \\
\hline $\mathrm{H}$ & 8,9 & 1 & 25 & 26 \\
\hline I & 8,12 & 1 & 25 & 26 \\
\hline $\mathrm{J}$ & 7,10 & 1 & 25 & 26 \\
\hline K & 7,11 & 2 & 24 & 26 \\
\hline $\mathrm{L}$ & 7,12 & 7 & 19 & 26 \\
\hline $\mathrm{D}_{1}$ & 9,12 & 0 & 26 & 26 \\
\hline $\mathrm{D}_{2}$ & 10,12 & 0 & 26 & 26 \\
\hline $\mathrm{D}_{3}$ & 11,12 & 0 & 26 & 26 \\
\hline $\mathrm{M}$ & 12,13 & 7 & 16 & 33 \\
\hline $\mathrm{N}$ & 13,14 & 7 & 33 & 40 \\
\hline $\mathrm{O}$ & 14,15 & 1 & 40 & 41 \\
\hline
\end{tabular}

Setelah diperolehnya hasil perhitungan waktu kejadian paling cepat (WKC) dan waktu kejadian paling lambat (WKL), diagram jaringan kerja untuk kegiatan verifikasi koleksi buku di perpustakaan akan terlihat seperti gambar berikut. 


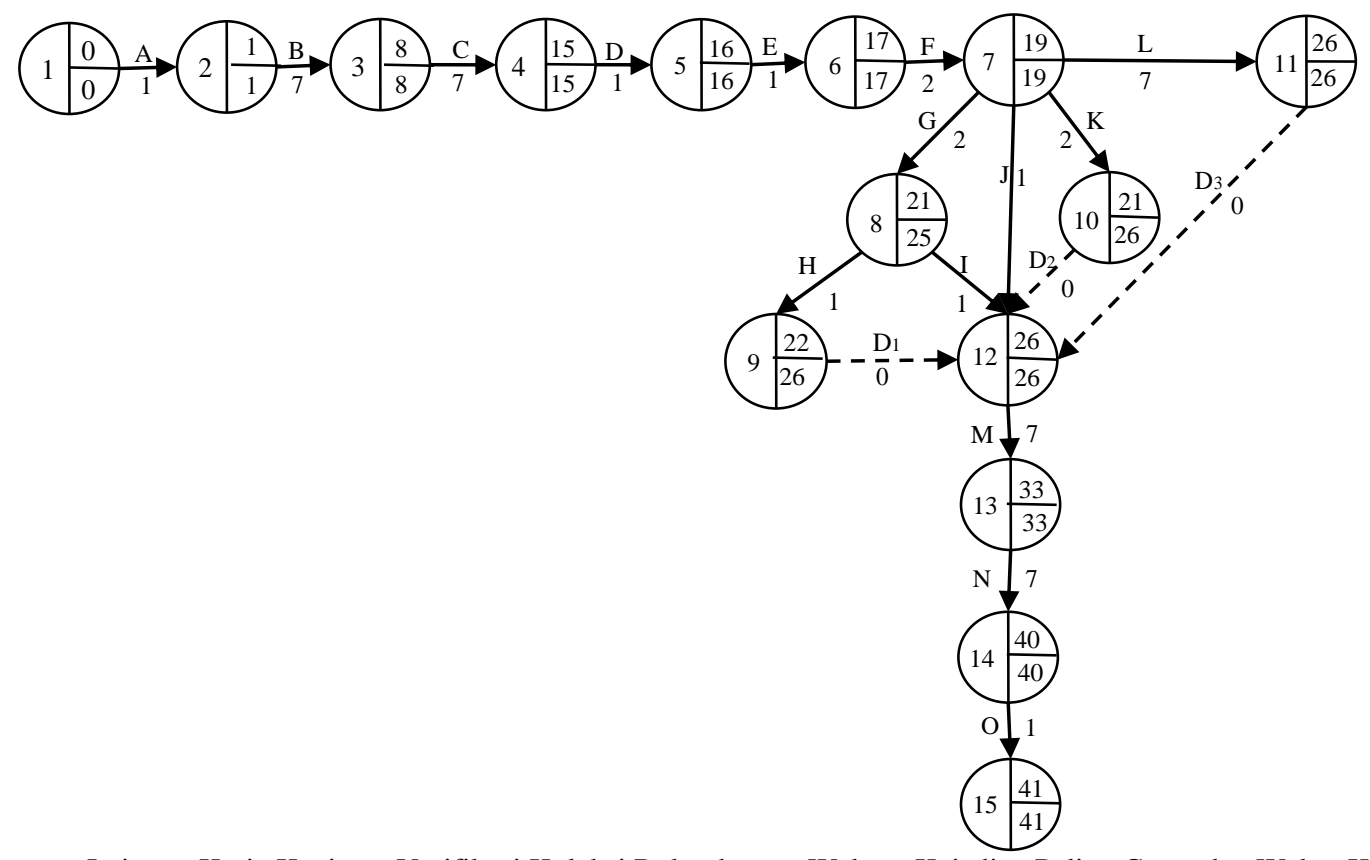

Gambar 4. Diagram Jaringan Kerja Kegiatan Verifikasi Koleksi Buku dengan Waktu Kejadian Paling Cepat dan Waktu Kejadian Paling Lambat

Waktu mengambang suatu kegiatan adalah selisih antara waktu yang diperlukan oleh jalur kritis dengan waktu yang diperlukan oleh jalur yang tak krtisi. Keterlambatan waktu dalam jalur tak kritis tidak mempengaruhi selesainya seluruh proyek, tetapi harus diperhitungkan berapa lama waktu mengambang yang diperkenankan untuk setiap kegiatan sehingga tidak mengganggu kegiatan yang dilalui jalur kritis.
Berdasarkan diagram jaringan kerja kegiatan verifikasi koleksi buku yang dilakukan di perpustakaan SMA Negeri 2 Medan yang memuat waktu kejadian paling cepat (WKC) dan waktu kejadian paling lambat (WKL) dapat dihitung waktu mengambang total (WMT) dan waktu mengambang bebas (WMB) dari setiap kegiatan. Waktu mengambang total (WMT) dapat dilihat pada Tabel 4 .

Tabel 4. Waktu Mengambang Total dari Kegiatan Verifikasi Koleksi Buku di Perpustakaan SMA Negeri 2 Medan

\begin{tabular}{|c|c|c|c|c|c|}
\hline Kegiatan & $\begin{array}{c}\text { Kode } \\
\text { Kegiatan }\end{array}$ & $(\mathbf{W S L})_{\mathrm{ij}}$ & $(\mathbf{W M C})_{\mathrm{ij}}$ & $\begin{array}{c}\text { Waktu } \\
\text { Pelaksanaan } \\
\text { (hari) Wij }\end{array}$ & $(\mathbf{W M T}) \mathbf{i j}$ \\
\hline A & 1,2 & 1 & 0 & 1 & 0 \\
\hline $\mathrm{B}$ & 2,3 & 8 & 1 & 7 & 0 \\
\hline $\mathrm{C}$ & 3,4 & 15 & 8 & 7 & 0 \\
\hline $\mathrm{D}$ & 4,5 & 16 & 15 & 1 & 0 \\
\hline $\mathrm{E}$ & 5,6 & 17 & 16 & 1 & 0 \\
\hline $\mathrm{F}$ & 6,7 & 19 & 17 & 2 & 0 \\
\hline $\mathrm{G}$ & 7,8 & 25 & 19 & 2 & 4 \\
\hline $\mathrm{H}$ & 8,9 & 26 & 21 & 1 & 4 \\
\hline $\mathrm{I}$ & 8,12 & 26 & 21 & 1 & 4 \\
\hline $\mathrm{J}$ & 7,12 & 26 & 19 & 1 & 6 \\
\hline K & 7,10 & 26 & 19 & 2 & 5 \\
\hline $\mathrm{L}$ & 7,11 & 26 & 19 & 7 & 0 \\
\hline $\mathrm{D}_{1}$ & 9,12 & 26 & 22 & 0 & 4 \\
\hline $\mathrm{D}_{2}$ & 10,12 & 26 & 21 & 0 & 5 \\
\hline$D_{3}$ & 11,12 & 26 & 26 & 0 & 0 \\
\hline $\mathrm{M}$ & 12,13 & 33 & 26 & 7 & 0 \\
\hline $\mathrm{N}$ & 13,14 & 40 & 33 & 7 & 0 \\
\hline $\mathrm{O}$ & 14,15 & 41 & 40 & 1 & 0 \\
\hline
\end{tabular}

Hasil perhitungan waktu mengambang dari setiap kegiatan dapat memperlihatkan kegiatan-kegiatan yang dilalui oleh jalur kritis sehingga hal tersebut menjadi pertimbangan bagi pihak pengelola perpustakaan dalam menjadwalkan kegiatan verifikasi koleksi buku agar tidak terjadi keterlambatan dalam penyelesaian kegiatan tersebut. Setelah diperoleh waktu mengambang total (WMT) dari setiap kegiatan dapat juga dihitung waktu mengambang bebas (WMB) dari setiap kegiatan yang dapat dilihat pada Tabel 5 .

Tabel 5. Waktu Mengambang Bebas dari Kegiatan Verifikasi Koleksi Buku di Perpustakaan SMA Negeri 2 Medan 


\begin{tabular}{|c|c|c|c|c|c|}
\hline Kegiatan & $\begin{array}{c}\text { Kode } \\
\text { Kegiatan }\end{array}$ & $(\mathbf{W K C})_{\mathbf{j}}$ & $(\mathbf{W K C})_{\mathbf{i}}$ & $\begin{array}{c}\text { Waktu } \\
\text { Pelaksanaan } \\
\text { (hari) Wij }\end{array}$ & $(\mathbf{W M B}) \mathbf{i j}$ \\
\hline $\mathrm{A}$ & 1,2 & 1 & 0 & 1 & 0 \\
\hline $\mathrm{B}$ & 2,3 & 8 & 1 & 7 & 0 \\
\hline $\mathrm{C}$ & 3,4 & 15 & 8 & 7 & 0 \\
\hline $\mathrm{D}$ & 4,5 & 16 & 15 & 1 & 0 \\
\hline$E$ & 5,6 & 17 & 16 & 1 & 0 \\
\hline $\mathrm{F}$ & 6,7 & 19 & 17 & 2 & 0 \\
\hline $\mathrm{G}$ & 7,8 & 21 & 19 & 2 & 0 \\
\hline $\mathrm{H}$ & 8,9 & 22 & 21 & 1 & 0 \\
\hline $\mathrm{I}$ & 8,12 & 22 & 21 & 1 & 0 \\
\hline $\mathrm{J}$ & 7,12 & 26 & 19 & 1 & 6 \\
\hline $\mathrm{K}$ & 7,10 & 21 & 19 & 2 & 0 \\
\hline $\mathrm{L}$ & 7,11 & 26 & 19 & 7 & 0 \\
\hline $\mathrm{D}_{1}$ & 9,12 & 26 & 22 & 0 & 4 \\
\hline $\mathrm{D}_{2}$ & 10,12 & 26 & 21 & 0 & 5 \\
\hline $\mathrm{D}_{3}$ & 11,12 & 26 & 26 & 0 & 0 \\
\hline $\mathrm{M}$ & 12,13 & 33 & 26 & 7 & 0 \\
\hline $\mathrm{N}$ & 13,14 & 40 & 33 & 7 & 0 \\
\hline $\mathrm{O}$ & 14,15 & 41 & 40 & 1 & 0 \\
\hline
\end{tabular}

Berdasarkan Tabel 4 dan Tabel 5 ditemukan kegiatan yang memiliki waktu mengambang nol, yaitu: A, B, C, D, E, F, L, D ${ }_{3}$, M, N, O. Kegiatan yang memiliki waktu mengambang nol merupakan kegiatan kritis atau kegiatan yang dilalui oleh jalur kritis yang harus dilakukan penjadwalan yang tepat untuk menghindari keterlambatan penyelesaian kegiatan verifikasi koleksi buku. Setelah diketahui kegiatan-kegiatan yang dilalui oleh jalur kritis dapat digambarkan diagram jaringan kerjanya seperti pada Gambar 5.

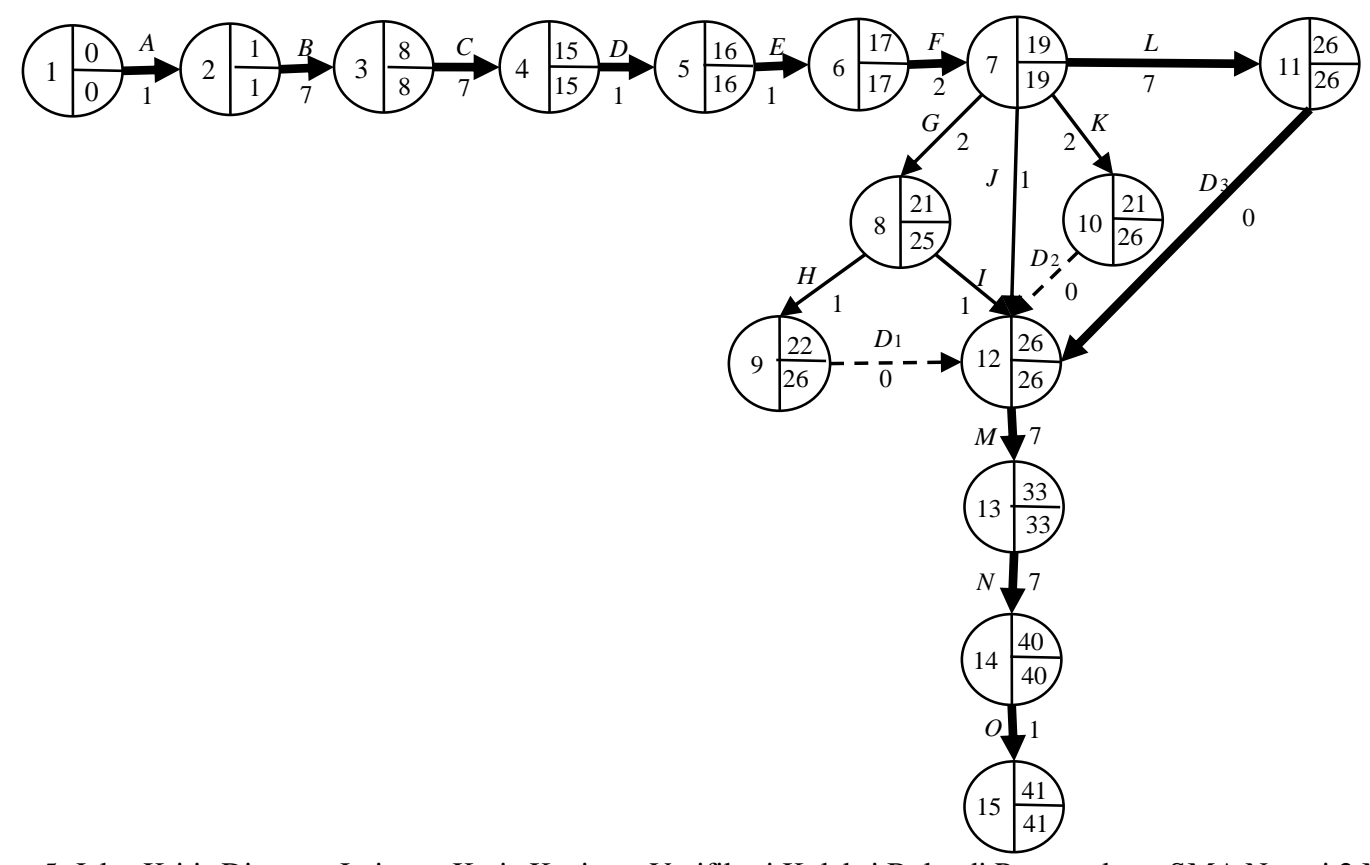

Gambar 5. Jalur Kritis Diagram Jaringan Kerja Kegiatan Verifikasi Koleksi Buku di Perpustakaan SMA Negeri 2 Medan

Pada saat penelitian kegiatan verifikasi koleksi buku ini, para pegawai yang melaksanakan kegiatan verifikasi bekerja sesuai dengan tugasnya masing-masing. Setelah diperoleh hasil penelitian dari penerapan analisis jaringan kerja pada kegiatan verifikasi koleksi buku yang dilakukan di perpustakaan SMA Negeri 2 Medan ternyata penerapan analisis jaringan kerja dapat digunakan dalam mengendalikan waktu pelaksanaan kegiatan verifikasi koleksi buku.

Analisis jaringan kerja dapat diterapkan pada kegiatan verifikasi koleksi buku di perpustakaan untuk mengetahui jadwal kegiatan verifikasi, sehingga tidak terjadi kelambatan dalam kegiatan verifikasi dan kegiatan ini dapat berjalan dengan lancar (Wahyudi, 2013).

\section{KESIMPULAN}

Berdasarkan hasil penelitian yang telah dijelaskan dapat disimpulkan sebagai berikut:

1. Kegiatan verifikasi koleksi buku di perpustakaan SMA Negeri 2 Medan yang telah dibuat menjadi diagram jaringan kerja yang memuat waktu kejadian paling cepat (WKC) dan waktu kejadian paling lambat (WKL) didapat waktu terpendek untuk menyelesaikan kegiatan tersebut adalah selama 41 hari dengan perkiraan waktu normal.

2. Penyelesaian kegiatan verifikasi koleksi buku dapat diselesaikan lebih awal dari waktu yang direncanakan 
apabila jumlah petugas yang menyelesaikan kegiatan tersebut ditambah.

3. Kegiatan-kegiatan yang dapat dipercepat waktu penyelesaiannya adalah kegiatan A, kegiatan B, kegiatan C, kegiatan D, kegiatan E dan kegiatan $\mathrm{M}$.

4. Apabila kegiatan A, kegiatan D, kegiatan E dipercepat setengah hari dan kegiatan $\mathrm{B}$, kegiatan $\mathrm{C}$ dan kegiatan $\mathrm{M}$ dipercepat satu hari, maka waktu penyelesaian kegiatan verifikasi koleksi buku tersebut adalah selama $36 \frac{1}{2}$ hari.

5. Keterlambatan penyelesaian kegiatan verifikasi koleksi buku terjadi karena disebabkan beberapa faktor yaitu:

a. Padamnya arus listrik sehingga menyebabkan terganggunya kegiatan menginput data ke komputer.

b. Hilangnya data inventaris buku yang sebelumnya.

c. Pengecekan data buku dengan yang ada pada pangkalan data masih secara manual.

6. Kegiatan-kegiatan yang dapat terlambat akibat beberapa faktor tersebut adalah kegiatan D, kegiatan J, kegiatan L dan kegiatan $\mathrm{O}$.

7. Apabila kegiatan $\mathrm{D}$, kegiatan $\mathrm{J}$, kegiatan $\mathrm{L}$ dan kegiatan $\mathrm{O}$ terlambat satu hari, maka waktu penyelesaian kegiatan verifikasi koleksi buku adalah selama 44 hari.

Berdasarkan dari simpulan diatas menunjukkan bahwa analisis jaringan kerja biasanya tidak menjamin bahwa waktu kerja sebagai waktu yang diperpendek atau waktu yang diperpanjang, waktu penyelesaian seluruhnya dapat dipercepat ataupun diperlambat. Kemudian analisis jaringan kerja dapat mengoptimalkan waktu penyelesaian kegiatan verifikasi koleksi buku.

\section{DAFTAR PUSTAKA}

[1] Agustini, D.H., \& Rahmadi Y.E. Riset Operasional KonsepKonsep Dasar. Jakarta: Rineke Cipta. 2004.

[2] Ayu, N. Perancangan Perangkat Lunak Pembentukan Jalur Kritis dari Suatu Jaringan Kerja Proyek. Skripsi tidak diterbitkan. Medan: Universitas Sumatera Utara. 2010.

[3] Ervianto, W.I. Manajemen Proyek Konstruksi. Yogjakarta: Andi. 2005.

[4] Handoko, T.H. Dasar-Dasar Manajemen Produksi dan Operasi. Yogjakarta: BPFE. 2000.

[5] Maranresy, P. dkk. Sistem Pengendalian Waktu Pada Pekerjaan Konstruksi Jalan Raya dengan Menggunakan Metode CPM. Jurnal Sipil Statik. Vol 3(1), pp: 8-15. 2015.

[6] Mulyono, S. Riset Operasi. Jakarta: LPEF. 2002.

[7] Prastowo, A. Manajemen Perpustakaan Sekolah Profesional. Yogjakarta: Diva Press. 2012.

[8] Siagian, P. Penelitian Operasional Teori dan Praktek. Jakarta: UIP. 1987.

[9] Sundari, T.S, dkk. Petunjuk Teknis Stock Opname Koleksi Perpustakaan. Bogor: Pusat Perpustakaan dan Penyebaran Teknologi Pertanian. 2012.

[10] Wahyudi, E. Penerapan Analisis Jaringan Kerja pada Kegiatan Verifikasi Koleksi Buku di Perpustakaan. Skripsi tidak diterbitkan. Medan: Universitas Negeri Medan. 2013. 